SECTION 24. Sociological research.

Gogoreva Victoria Nikolaevna

student,

Siberian State Aerospace University,

Russia

\title{
PUNISHMENT OF CHILDREN IS A PROBLEM, HOW TO AVOID THE PSYCHOLOGICAL EFFECTS
}

Annotation: Nowadays parents can not find a common language with their children. This article discusses some aspects of the problem. Let's try to understand this situation.

Key words: family, problems.

\section{ПРОБЛЕМА НАКАЗАНИЯ ДЕТЕЙ, КАК ИЗБЕЖАТЬ ПСИХОЛОГИЧЕСКИХ ПОСЛЕДСТВИЙ}

Аннотация: В настоящее время родители не могут найти общий язык со своими детьми. В данной статье рассматриваются некоторые аспекты проблемы. Давайте попробуем разобраться в этой ситуаиии.

Ключевые слова: семья, проблемы.

Проблема, описанная в статье, заключается в том, что наказание следовать должно, но следовать за тем, что вы называете нарушением. Поэтому, прежде чем оттачивать своё педагогическое мастерство, определите рамки, которые малышу нельзя нарушать.

Большинство россиян, принявших участие в опросе Исследовательского центра рекрутингового портала SuperJob., расценивают меры физического воздействия на детей (шлепки, подзатыльники) как допустимую составляющую воспитательного процесса, однако применять их считают возможным только в крайних случаях.

Физическое наказание ребёнка - это проявление бессилия и неуравновешенности взрослого или же законное право родителя, подкрепляющее его авторитет? Как оказалось, большая часть россиян (73\%) считает шлепки и подзатыльники вполне допустимой мерой воздействия на детей, однако 63\% из них уточняют, что такое «внушение» возможно лишь в исключительных случаях, к примеру, «в случае серьёзных проступков» или «когда уговоры не действуют». Иными словами, применять силу можно, когда все словесные доводы исчерпаны, но ребёнок так и не осознал своей неправоты и не прислушался к старшим. «Если ребёнка вовремя не приструнить, то он сядет на шею и будет погонять до самой старости», - уверяют респонденты. Стоит отметить, что за последние четыре года число россиян, полагающих, что шлёпать детей за плохое поведение хоть и редко, но стоит, увеличилось - с 58\% в 2006 году до 63\% в нынешнем. Возросло и количество тех, кто свято верит в то, что ремень в доме нужен не только для поддержания брюк, но и для воспитания нерадивых отпрысков, - с 8\% в 2006-м до $10 \%$ в текущем году. Неудивительно, что мужчин, считающих порку и подзатыльники необходимым методом воспитания, заметно больше - 13\% и 8\% соответственно. И чем старше опрошенные, тем чаще они придерживаются этой точки зрения. При этом некоторые россияне считают, что данная воспитательная мера применима лишь к маленьким 
детям: «Да. До трёх лет»; «Считаю это необходимым исключительно для парней и до определённого возраста, лет до 5».

Абсолютно неприемлемым методом воспитания детей считают физическое наказание $27 \%$ россиян. «Такой вид донесения информации - удел людей с ограниченными речевыми и умственными возможностями»; «Нет, это унижает личность. Всё можно объяснить словами и примерами», - уверены участники опроса. По их словам, «воспитать добродушного, открытого и честного человека можно без единого шлепка или подзатыльника». Любое телесное наказание предполагает причинение боли, но эта боль мыслится временной и не сопряженной с телесным увечьем. Большинство родителей не хотят причинять своему ребенку боль, однако фактически наказанием, вызывающим у ребенка страх и заставляющим его слушаться, является именно боль. Поскольку родители больше и сильнее ребенка, то любое телесное наказание содержит в себе возможность членовредительства, насилия и злоупотребления властью. Самое страшное то, что родители этой опасности не замечают. Из бесед с родителями, привлеченными к ответственности за насилие в отношении своих детей, видно, что почти две трети подобных случаев начинались как акты телесного наказания с целью исправления неправильного поведения ребенка. Это самый распространенный и практически универсальный мотив насилия над детьми. 75\% всех зарегистрированных в Канаде в 2003 г. актов физического насилия над детьми начинались и трактовались родителями как справедливые, заслуженные ребенком, телесные наказания (Durrant et al., 2006). Не имея системной информации о личности обвиняемого, никакой эксперт не сможет однозначно определить, где тут «подлинный мотив», а где - ретроспективное оправдание (легитимация) собственной жестокости.

Каковы же мотивы наказания родителями детей?

По данным опроса можно сделать вывод, что современные родители, как правило, применяют к своим детям те методы воспитания, с которыми сами сталкивались в детстве. Так, если в угол своих детей ставят в среднем $43 \%$ родителей, то среди тех, кого так наказывали родители в детстве, таких 64\%. Что касается телесных наказаний, то их применяет только треть родителей в целом (33\%) и половина тех, кто сталкивался с этим в своем детстве (52\%). Что касается такой меры как лишение карманных денег, то сейчас ее применяют $23 \%$ опрошенных родителей и $51 \%$ тех, кого так наказывали в детстве.

В качестве наказания лучше использовать лишение чего-либо важного для ребёнка, но не жизненно необходимого. Ни в коем случае нельзя лишать еды (в случае, если ребёнок сознательно портил её, следующий прием пищи должен быть более скромным, без деликатесов, но быть). Лучше наказать вниманием, но, не перегибая палку. Не разговаривать и уж тем более не реагировать на малыша 1-3 лет просто нельзя. Ни в коем случае нельзя наказывать: - за естественную познавательную активность - например, ребёнок берет в рот предметы, тычет пальчиком в разные дырочки или хочет познать функции какого-то предмета, т.е. сломал игрушку (свою или чужую - не нарочно), изучает свои половые органы; - за возрастные и физиологические особенности - неусидчив, невнимателен, не желает засыпать, не хочет есть; - за отсутствие опыта поведения в той или иной жизненной ситуации - не попросился на горшок и описался; плюется или дерется, если ранее ему не объяснили, что это плохо; отнимает игрушку; боится идти к врачу; - за проявление естественного чувства - ревность к младшему братику или сестренке; - за неосторожность испачкался на прогулке, случайно пролил сок из чашки. 
Данная проблема могла быть значительно сглажена, если бы Родители задумывались, а именно:

- Не ругали и не наказывали детей за пустяки;

- Больше внимания уделяли ребенку;

- Старались объяснить правильно «что можно, что нельзя»;

- Не отбирать вещи которые помогают развитию.

\section{Список литературы:}

1. Ада Делла Торре. Ошибки родителей.-М.: Прогресс 1984.

2. Азаров Ю.П. Семейная педагогика. - М., 1982. 